\title{
Technè
}

La science au service de l'histoire de l'art et de la préservation des biens culturels

45 | 2017

Bronzes grecs et romains : études récentes sur la statuaire antique

\section{Termini ante quos: Bronze statuary from Late Hellenistic shipwrecks}

Termini ante quos : la statuaire en bronze provenant d'épaves de

l'Hellénistique tardif

\section{Polyxeni Bouyia}

\section{OpenEdition \\ Journals}

Electronic version

URL: http://journals.openedition.org/techne/1242

DOI: 10.4000/techne.1242

ISSN: 2534-5168

\section{Publisher}

C2RMF

\section{Printed version}

Date of publication: 1 May 2017

Number of pages: $24-33$

ISBN: 978-2-7118-6408-9

ISSN: $1254-7867$

\section{Electronic reference}

Polyxeni Bouyia, «Termini ante quos: Bronze statuary from Late Hellenistic shipwrecks », Technè [Online], 45 | 2017, Online since 19 December 2019, connection on 23 July 2020. URL : http:// journals.openedition.org/techne/1242 ; DOI : https://doi.org/10.4000/techne.1242

\section{(c) $($ ) $\odot$ (S)}

La revue Technè. La science au service de l'histoire de l'art et de la préservation des biens culturels est mise à disposition selon les termes de la Licence Creative Commons Attribution - Pas d'Utilisation Commerciale - Pas de Modification 4.0 International. 


\section{Polyxeni Bouyia (1959-2013)}

$\mathrm{P}$ olyxeni Bouyia, disparue quelques mois seulement après la journée d'études sur la datation des grands bronzes antiques en février 2013, avait accepté notre invitation malgré son état de santé fragile. Nous lui en avions été infiniment reconnaissants. Outre la très belle synthèse qu'elle avait présentée sur l'importance des épaves de la fin de l'époque hellénistique pour la chronologie de la statuaire métallique, elle avait participé avec rigueur et précision aux débats suscités par les différentes interventions et nous avions pu apprécier alors l'étendue de ses connaissances.

Polyxeni Bouyia s'intéressait aux institutions antiques, à l'épigraphie, à la numismatique, à la céramique, à l'architecture et à la topographie, de la Grèce centrale principalement. Elle avait assuré, de 1994 à 2007, la responsabilité de plusieurs fouilles de sauvetage de cimetières et d'anciens habitats de la Phthiotide et d'Athènes, comme archéologue d'État au Service archéologique grec. Directeur adjoint de la quatorzième Éphorie des Antiquités préhistoriques et classiques des préfectures de Phthiotide et d'Eurytanie (1995-2001) puis numismate au Musée numismatique d'Athènes (2001-2003), elle était entrée ensuite comme archéologue à la troisième

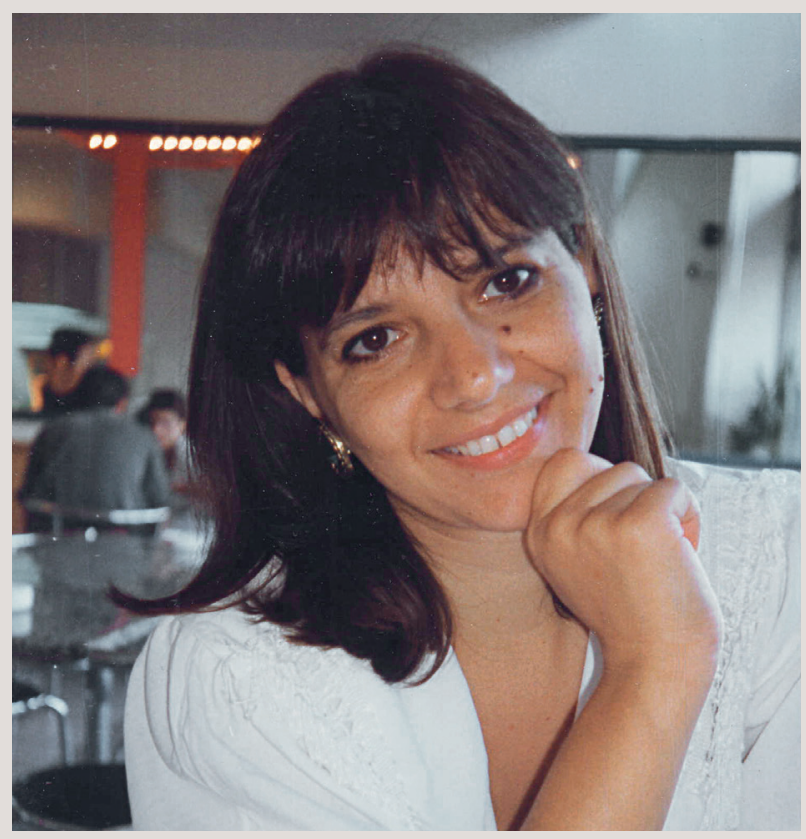

Éphorie des Antiquités préhistoriques et classiques d'Athènes (2003-2007). Depuis 2007, elle était chargée de la collection des bronzes antiques au Musée national archéologique d'Athènes. Elle fut, auprès de Nikolaos Kaltsas, l'un des commissaires de la remarquable exposition sur l'épave d'Anticythère (The Antikythera Shipwreck: The ship - The Treasures - The Mechanism (Athens, National Archaeological Museum, April 2012- April 2013), Athènes 2012).

Ses travaux scientifiques illustrent bien la multiplicité de ses centres d'intérêt. Il est impossible de tous les citer ici. Notre sélection est nécessairement arbitraire. On mentionnera sa thèse de doctorat sur les ponts antiques de Grèce et de la côte d'Asie Mineure, publiée en 1996, et la même année, un article sur les ponts de bateaux. En 1998, elle présentait une communication sur les sites fortifiés de la Locride orientale ; en 2000, sur la céramique du cimetière hellénistique d'Echinos ; en 2001, sur un trésor monétaire hellénistique de Stylis en Grèce centrale ; en 2004, sur la collection d'intailles et de camées de Konstantin Karapanos ; en 2005, sur le mobilier céramique de la nécropole hellénistique de Narthakion ; en 2006, sur les sanctuaires de la Mère des dieux-Cybèle dans les villas urbaines athéniennes de l'époque romaine tardive ou encore en 2012, sur les divinités et sanctuaires dans la vallée du Spercheios.

Polyxeni Bouyia était une collègue accessible, positive, toujours réactive. Sa disparition prématurée nous a profondément frappés et nous ne savions pas comment honorer sa mémoire dans le cadre de ces actes, doutant de retrouver l'article auquel aurait dû aboutir sa communication parisienne. Or le texte qu'elle nous destinait nous attendait. Il était même entièrement rédigé et nous ne remercierons jamais assez sa sœur, Irène Bougia, pour son accueil, sa disponibilité et sa ténacité. Elle a exploré pour nous, avec les indices que nous lui avions donnés, les différents fichiers de l'ordinateur de Polyxeni. Et nous avons été tellement heureux lorsqu'elle nous a annoncé que l'article existait bien. Notre gratitude va également à Kalliopi Kritikakou, pour sa relecture du texte, ainsi qu'à Giorgos Kavvadias, collègue de Polyxeni alors qu'elle occupait son dernier poste au Musée national archéologique d'Athènes et à Moncef Ben Moussa, conservateur en chef du Musée national du Bardo à Tunis. Tous deux nous ont permis d'illustrer son article avec plusieurs photographies des bronzes d'Anticythère et de Mahdia, une manière collective de lui rendre ainsi hommage. 


\section{Polyxeni Bouyia $†$ \\ Termini ante quos: Bronze statuary from Late Hellenistic shipwrecks}

Termini ante quos : la statuaire en bronze provenant d'épaves de l'Hellénistique tardif

\begin{abstract}
Five shipwrecks dated to ca. 150-50 B.C. comprised - among other commodities - bronze statuary. In a few other cases, fragmentary statues have been found out of context, as a result of pillage or, less often, of mercantile transactions. Bronzes were very popular to Roman and other western aristocrats and businessmen, since they were considered to be ideal for the ostentatious decoration of country and seaside villas. The bronze cargoes attest to the popularity and circulation of these particular works of art. The dates of these exceptional shipwrecks, obtained through examination of all the finds, offer a terminus ante quem for the date of manufacture of the bronzes they contained. Since the procedure involved in the production of both large and small-scale bronzes is essentially the same, practices and manufacturing techniques that are evident in the bronzes of the wrecks can provide useful chronological criteria for dating bronze replicas.
\end{abstract}

Keywords. Late Hellenistic shipwrecks, bronze statuary, serially-produced bronzes, manufacturing techniques, dating of ancient bronze replicas.
Résumé. Cinq épaves datant de la période 150-50 avant J-C. comportaient, parmi d'autres biens, de la statuaire en bronze. Dans quelques autres cas, des fragments de statues ayant fait l'objet de pillages ou, plus rarement, de transactions commerciales ont été trouvés hors contexte. Les bronzes étaient très en vogue auprès de l'élite aristocratique et des entrepreneurs de Rome et des contrées occidentales car ils étaient considérés comme l'idéal des fastes de la décoration des villas de campagne et de bord de mer. Les cargaisons de bronze témoignent de la faveur et de la circulation de ces cuvres d'art. La datation de ces épaves exceptionnelles, fondée sur l'examen de l'ensemble des trouvailles que le bateau transportait, offre un terminus ante quem pour la date de fabrication des bronzes qu'elles renferment. Étant donné que la production des bronzes de grand et de petit format repose essentiellement sur les mêmes procédés, l'étude des pratiques et des techniques de fabrication des bronzes provenant d'épaves peut donc fournir d'utiles critères chronologiques pour la datation des répliques de bronze.

Mots-clés. Épaves, Hellénistique tardif, statuaire en bronze, production de bronzes en série, techniques de fabrication, datation des répliques de bronze.
Of the 62 shipwrecks dating to the period ca. 150-50 B.C., only five (see Table 1) contain a cargo of bronze statuary and/ or accessories ${ }^{1}$. Acquired as spoils of war or through voluntary or forcible exchange and intended for members of the Roman and Gaulish elite, the bronzes offer an insight into the popularity and circulation of particular works of art. The dates of these exceptional shipwrecks, obtained through examination of all the finds, offer a terminus ante quem for the date of manufacture of their bronze cargo.

These maritime accidents (naufragia) occurred at a time when the inability to meet demand on the part of aristocrats and businessmen for works of art from the spoils of the Roman war machine intensified the then unprecedented practice of trading in such objects. As a result, there was a boom in the production of copies, transformations that often interpreted the original in a very free spirit, and of creations inspired by older periods ${ }^{2}$. The fullest set of serially-produced bronzes was carried by a ship which sank off Mahdia ${ }^{3}$, on the coast of Tunisia. Its cargo is comparable to that of the Antikythera shipwreck $^{4}$ and, to a lesser extent, with that of the smaller Fourmigue $\mathrm{C}$ shipwreck ${ }^{5}$ off Cannes, on the French coast. Both the Mahdia and Fourmigue $\mathrm{C}$ ships are thought to have begun their journey from the Piraeus ${ }^{6}$, whereas the Antikythera freighter is thought to have set out from somewhere in the central-eastern Aegean area, such as Delos, Pergamon or Ephesos ${ }^{7}$. Since the procedure involved in the production of both large and small-scale bronzes is essentially the same, practices and manufacturing techniques that are evident in the bronzes of the wrecks can provide useful chronological criteria for dating bronze replicas. Furthermore, their subjects illustrate prevailing aesthetic trends and might also offer some help in dating the objects in question. 
Table 1. Late Hellenistic shipwrecks with artworks

\begin{tabular}{|c|c|c|c|c|}
\hline $\mathbf{N}^{\mathbf{o}}$ & SHIPWRECK & EQUIPMENT & CARGO & DATE \\
\hline 1 & $\begin{array}{l}\text { Styra } 6 \\
\text { (Greece) }\end{array}$ & $\begin{array}{l}\text { Wood, nails, lead rings, tableware, stone } \\
\text { basin }\end{array}$ & $\begin{array}{l}\text { Amphorae of Brindisi and Kos, parts of } \\
\text { bronze statues, parts of iron couches, } \\
\text { tableware }\end{array}$ & ca. $130-50$ B.C. \\
\hline 2 & $\begin{array}{l}\text { Kalymnos } \\
\text { (Greece) }\end{array}$ & & Bronze statues, amphorae of Knidos & 100-50 B.C. \\
\hline 3 & $\begin{array}{l}\text { Mahdia } \\
\text { (Tunisia) }\end{array}$ & $\begin{array}{l}\text { Lead ingots, } 4 \text { lead parts from anchors, } \\
\text { millstones, pottery, amphorae, human } \\
\text { bones (fragments of bilge pump, } \\
\text { and lead sheathing) }\end{array}$ & $\begin{array}{l}\text { Marble columns, marble architectural parts, } \\
\text { bronze and marble statuary, bronze couches }\end{array}$ & 100-75 B.C. \\
\hline 4 & $\begin{array}{l}\text { La Fourmigue } \mathrm{C} \\
\text { (France) }\end{array}$ & $\begin{array}{l}\text { Mortar with grindstone, lamp of tin, } \\
\text { wooden discs from a kind of } \\
\text { infrastructure, plates of Campanian B } \\
\text { ware, coarse pots }\end{array}$ & $\begin{array}{l}\text { Amphorae Dr. IB, } 3 \text { Lam. } 2 \text {, } \\
2 \text { Dr. 1A, bronze couches, bronze pots, lamp } \\
\text { holder }\end{array}$ & ca. 80-60 B.C. \\
\hline 5 & $\begin{array}{l}\text { Antikythera } \\
\text { (Greece) }\end{array}$ & $\begin{array}{l}\text { Wooden planks, nails, sounding weights, } \\
\text { Megarian bowls, black glazed cups, } \\
\text { lamps, wine jugs (fragments of lead } \\
\text { sheathing and water pipes of bilge } \\
\text { pump) }\end{array}$ & $\begin{array}{l}\text { Statuary of bronze and marble, bronze } \\
\text { couches, glassware, pots of silver, pots of tin, } \\
\text { amphorae of Rhodes, Kos, Ephesos, Lam. 2, } \\
\text { pottery, silver and bronze coins of Pergamon } \\
\text { and Ephesos, bronze coins of Sicily, the } \\
\text { Mechanism }\end{array}$ & 75-50 B.C. \\
\hline
\end{tabular}

The cases of the statuary from Artemision (foundered in ca. 80 B.C.), Kalymnos (2nd-3rd quarter of 1st century B.C.), les Saintes-Maries-de-la-Mer (sunken in ca. 100 B.C.), and the Croatian coast (Apoxyomenos, dropped in the sea most probably in the 1st century B.C.) are more difficult to assess, since no shipwreck has been traced or at least raised (as in the case of the Artemision shipwreck). The famous Zeus or Poseidon (5th century B.C.) and the boy jockey with his horse (2nd century B.C.) off the Cape Artemision were collected together with items typically found on board (a bronze Chian coin with a boy rider on the obverse and a thyrsus in an ivy wreath on the reverse, an allegedly commemorative issue for the horse victory of a prominent person on the island, a lamp, worn West Slope cups and fragmentary Sigillata ware of the 2nd-1st century B.C., amphorae, iron and bronze nails, millstones, a grindstone and a lead anchor) ${ }^{8}$. In the 1920's, wood from the ship was detected in situ. At least, one ship carrying a bronze equestrian statue, possibly rendering a Macedonian ruler of Bactria with the typical headdress (kausia) ${ }^{9}$, and a Knidian amphora was wrecked off the island of Kalymnos in the 2nd-3rd quarter of the 1 st century B.C. ${ }^{10}$ The parts of the statue had been cast separately, as the left foot was detached from the body at the joint. A trawling off les Saintes-Maries-de-la-Mer brought to light a Hellenistic bronze statuette of a Satyr (51 cm high), amphorae and possibly column drums ${ }^{11}$.

Shipwreck Styra 6 (ca. 130-50 B.C.) carrying Brindisi and Koan amphorae, bronze statues, iron benches and terracotta tableware has not been published yet ${ }^{12}$. The Fourmigue $\mathrm{C}$ ship, which sank between ca. 80-60 B.C., had stored in her hold Dressel 1A, B and Lamboglia amphorae, bronze couches, a candelabrum, a bronze situla and pottery ${ }^{13}$. The couches are similar to those found on the Mahdia shipwreck.

The latter ship probably sank off Mahdia in the first quarter of the 1st century B.C. ${ }^{14}$ It contained a typically mixed cargo: columns, capitals, bases, kraters, candelabra, reliefs and inscriptions, statues (two male torsos, fragment of a youth, seven heads and busts), eight statuettes (four or five of Satyrs, two of Artemis and one of a seated boy) mainly of marble and a series of bronzes: a herm of Dionysos and a statue of a youth, figurines, fittings for furniture and vessels, candelabra, lamps, a brazier, couches, vases.

The marble sculptures of both the Mahdia and Antikythera ${ }^{15}$ shipwrecks were fashioned from pieces of Parian marble, which is not easily extractable in large blocks, and were joined together by means of wooden tenons or metal dowels. The Mahdia marble statues and statuettes have been assigned to Attic workshop $/ \mathrm{s}^{16}$.

Most of the bronzes of both shipwrecks were cast in sections. An Attic provenance, even one from a single workshop, has been assumed for the Mahdia bronzes too ${ }^{17}$. Andreas Linfert advanced the idea that a production unit, such as that of the family of the sculptor Boethos, who signed the bronze Dionysiac herm and was first active on Delos and, after its destruction, in Athens, may have provided bronzes - couches included - found in the shipwreck (i.e. originals, older pieces, and replicas) ${ }^{18}$. 


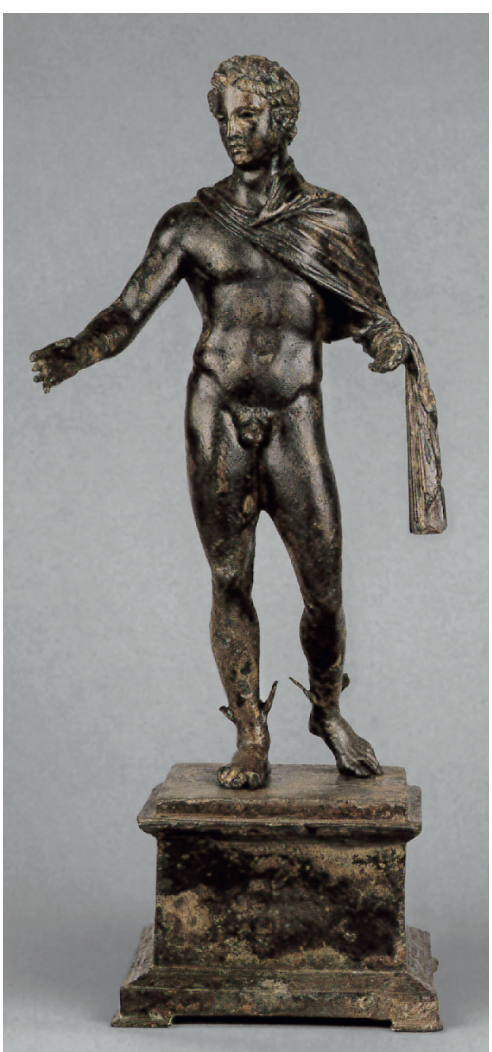

Fig. 1. Statuette of Hermes, Mahdia shipwreck, Tunis, Musée national du Bardo, inv. $n^{\circ}$ F 208. (C) Exhib. Bonn, 1994 : Das Wrack. Der antike Schiffsfund von Mahdia, pl. 13.

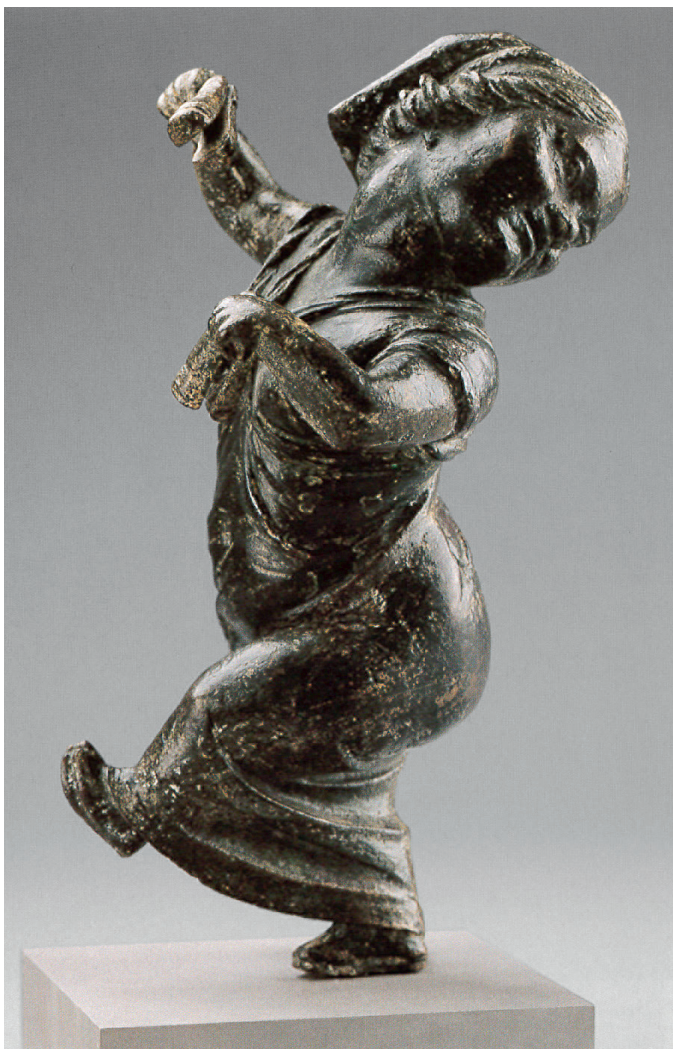

Fig. 2. Dancing female dwarf, Tunis, Musée national du Bardo, inv. $n^{\circ}$ F 213. (C) Exhib. Bonn, 1994 : Das Wrack. Der antike Schiffsfund von Mahdia, pl. 16.

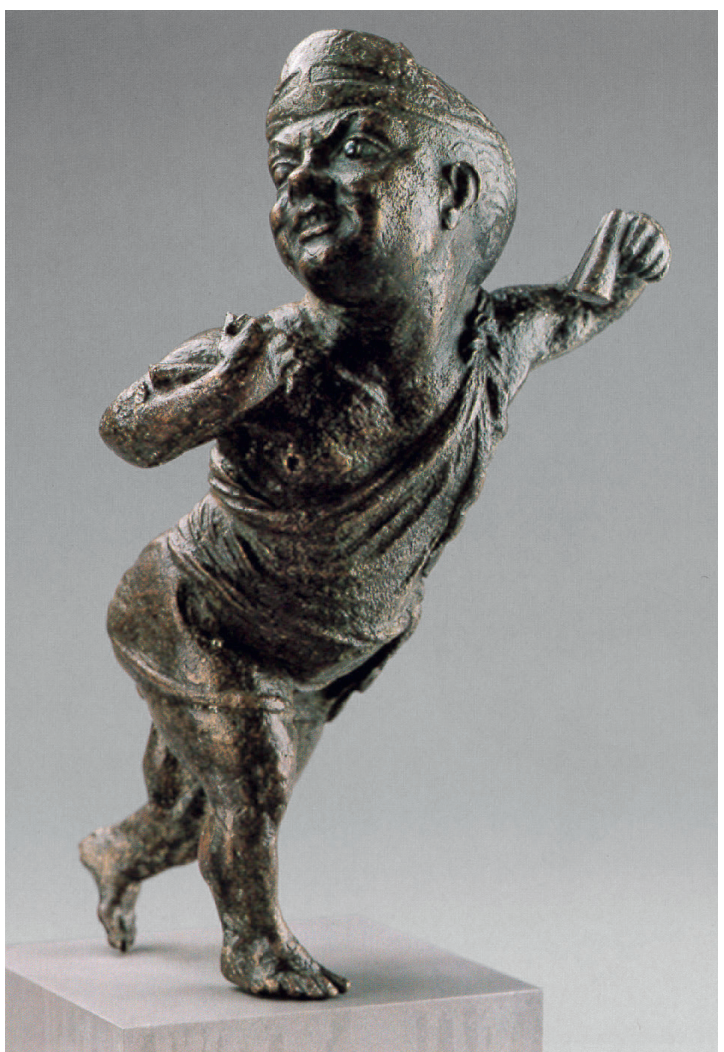

Fig. 3. Dancing dwarf, Tunis, Musée national du Bardo, inv. ${ }^{\circ} \mathrm{F} 215$. (C) Exhib. Bonn, 1994 : Das Wrack. Der antike Schiffsfund von Mahdia, pl. 17.
The classicizing statuette of Hermes (fig. 1, inv. $n^{\circ} \mathrm{F} 208$, height $32 \mathrm{~cm}$, height of base $10 \mathrm{~cm}$ ), which is in any case a not common specimen of the early-1st century B.C. for this particular deity, was mounted on a bronze base of the same century, while its torso is filled with lead from the left shoulder downwards in an unparalleled fashion ${ }^{19}$. Stylistic criteria suggest that this work is to be associated with Delos ${ }^{20}$. On that island, statuettes of Hermes, who was worshiped with Lares Compitales as shown in the Delian wall paintings, decorated rich Late Hellenistic mansions ${ }^{21}$.

A dining room or garden of a Roman villa would have been the ideal setting for the three dancing dwarfs, whose classicizing shiny surface and sharp garment folds are typical of the 1st century B.C. ${ }^{22}$ These figures are similar in terms of their forms and proportions, despite their reversed stances ${ }^{23}$. One female dancer (fig. 2, inv. $\mathrm{n}^{\mathrm{O}} \mathrm{F} 213$ ) is a mirror-image of the man (fig. 3, inv. $\mathrm{n}^{\circ} \mathrm{F} 215$ ) and the ivy-crowned girl (inv. $\mathrm{n}^{\circ} \mathrm{F} 214$ ). They were produced by means of a single basic model and its reverse. The extensive deviations from the original were possible thanks to the use of a large amount of wax in the master molds. On them, the individual features were carved. As Carol Mattusch has rightly noted, the weight of the figurines ( 3.59 and $4.18 \mathrm{~kg}$ ), which is disproportionate to their size $(30-32 \mathrm{~cm})$, confirms this argument.
The two lamp-bearers, a winged androgynous Eros (fig. 4, inv. $\mathrm{n}^{\circ} \mathrm{F} 216$ ) and a Hermaphrodite (fig. 5, inv. $\mathrm{n}^{\circ} \mathrm{F} 109$ ), made around 100 B.C., came from one original model, as is shown by their measurements (height $49 \mathrm{~cm}$ ) and poses. Modeling of, and alterations to the arms holding the torches, the addition of wings to the Eros, and of neck locks to the Hermaphrodite were executed on the wax models ${ }^{24}$. These pieces represent the evolution, in refined form, of the lychnouchoi which were produced somewhere in the eastern Mediterranean, probably Delos, for a short period ${ }^{25}$. This pair of figurines is reminiscent of the Hellenistic trend to use pairs of figures in the embellishment of Hellenistic houses ${ }^{26}$.

The lamp-bearers, the figurines of a kithara-playing Eros, and of a hurrying Satyr have been regarded by scholars as appropriate to the triclinium of a villa ${ }^{27}$, since their grouping would have given artistic form to the idea of the presence of servants charged with seeing to lighting, music and the serving of food in this room. This room would also provide the perfect setting for the figurine of a standing actor (inv. $\mathrm{n}^{\circ} \mathrm{F} 220$ ) and of a seated actor (inv. $\mathrm{n}^{\circ} \mathrm{F}$ 225) from the second half of the 2nd century B.C.

The pendant kithara-playing Eros (inv. $n^{\circ} \mathrm{F} 210$, height $42 \mathrm{~cm}$ ) shows stylistic and typological parallels with terracotta 


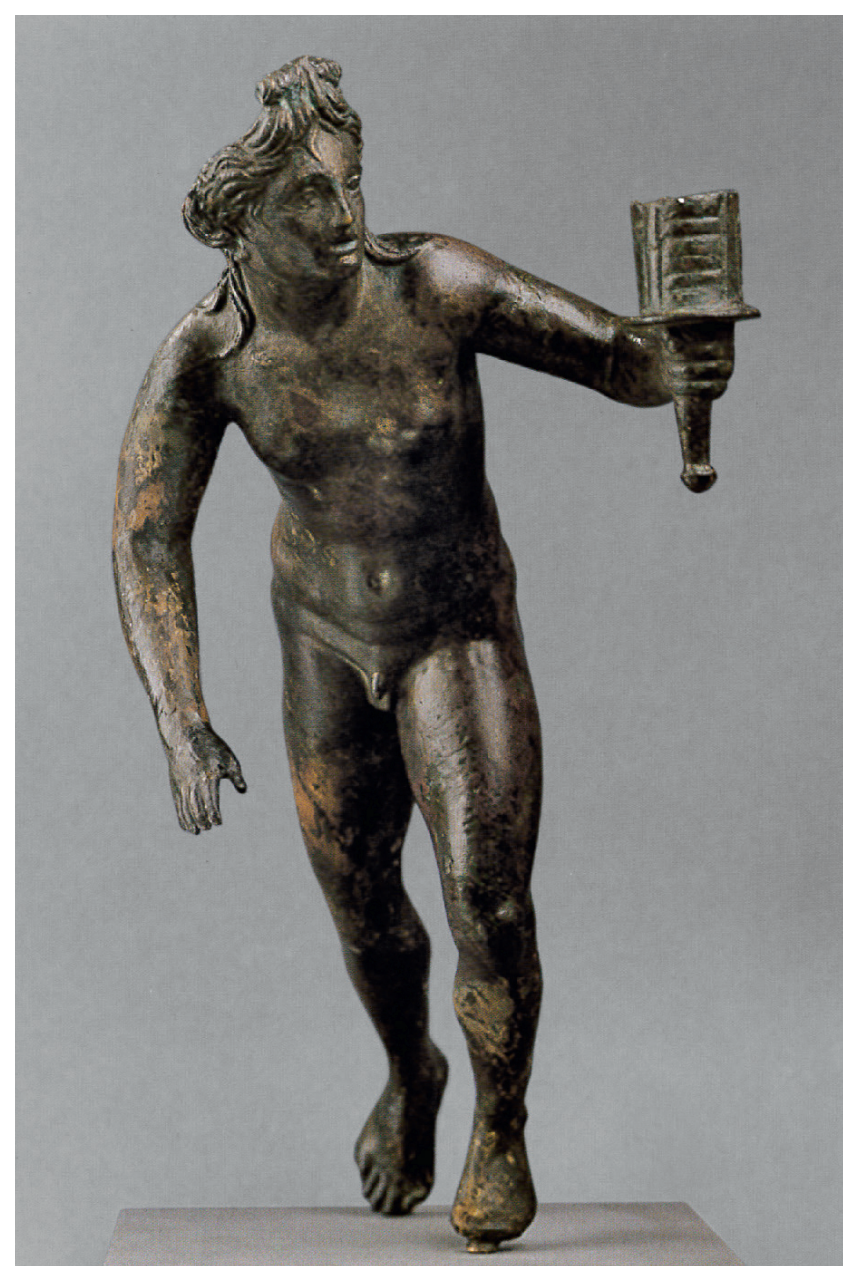

Fig. 4. Lamp-bearer: winged Eros, Tunis, Musée national du Bardo, inv. $n^{\circ}$ F 216. (C) Exhib. Bonn, 1994 : Das Wrack. Der antike Schiffsfund von Mahdia, pl. 20.

figurines of the 2nd century B.C. but differs technically and stylistically from the other bronzes of the shipwreck ${ }^{28}$. The large hurrying Satyr (inv. $n^{\circ}$ F 209, height $35 \mathrm{~cm}$ ), a work of the second half of the 2nd or the early-1st century B.C., very probably held a drinking cup $^{29}$ which may have functioned as container for fruit or delicacies ${ }^{30}$. The two small Satyrs (inv. $\mathrm{n}^{\mathrm{os}} \mathrm{F} 221$ and $\mathrm{F} 222$, height $20 \mathrm{~cm}$ ) are in fact appendages of a candelabrum decorated with acanthus branches, a composition archaeologically unparalleled for the time ${ }^{31}$. Literary reference to them is found in Pliny, Historia Naturalis, 34.14: "lychnuchi pensiles in delubris aut arborum mala ferentium modo lucentes." Despite the corrosion and certain variations between the two regarding their arm - one is playing the flute and the other is dancing -, the pair of Satyrs also seems to derive from a common original model. The standing comedian may have carried a platter with refined foodstuff, while the seated one may have served as a finial of a candelabrum, lamp or small table ${ }^{32}$.

Serial production, with variations executed on the waxes, is the main feature of the little bronzes and other equipment

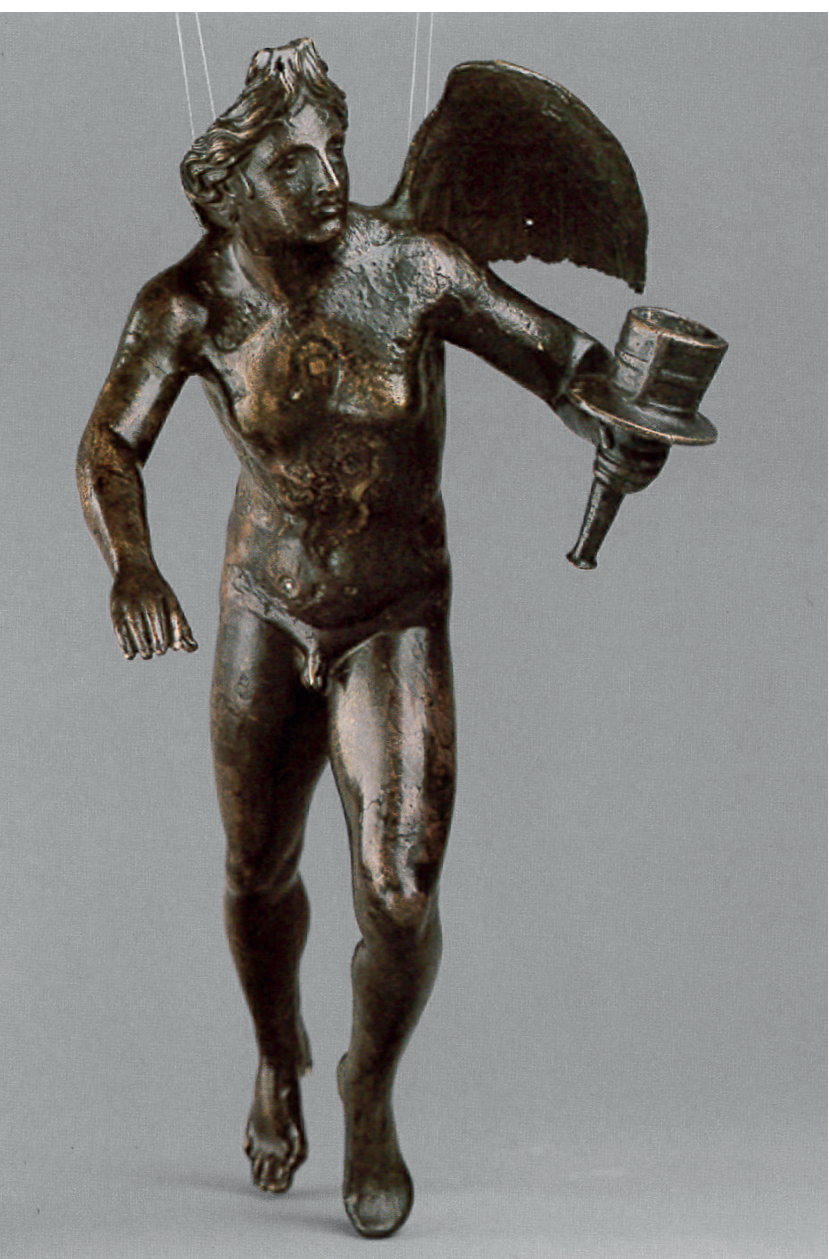

Fig. 5. Lamp-bearer: Hermaphrodite, Tunis, Musée national du Bardo, inv. nº F 109. (C) Exhib. Bonn, 1994 : Das Wrack. Der antike Schiffsfund von Mahdia, pl. 21.

from the Mahdia shipwreck. The bronze appliqués - two masks of Old Father from New Comedy, originally decorative attachments located under the handles of a situla; three plaques with griffins and a kraterfixed with nails to some piece of furniture; eight lion-griffins and four female panthers leaping in two different directions, respectively from a table and a bronze vessel; three Pan's heads from the lip of a vessel; two mirror-reversed reclining hounds appropriate for a chariot or wagon decoration, and two swimming ducks fastened on thongs, ropes or fillet - were mass-produced from the same ur-mold ${ }^{33}$. The couches with cast busts at their ends ${ }^{34}$ with a repertory from the world of Artemis, the candelabra ${ }^{35}$ and the bronze lamps ${ }^{36}$, and the brazier on rollers with the Satyr mask ${ }^{37}$ were likewise serially produced.

This manufacturing practice, i.e. the lost wax casting, appears for the first time in the Geometric period, but its technology relying on master-molds (indirect method) was refined, to reach a peak from the 2nd century B.C. onwards, in order to cater to the growing demands of Roman and other western aristocrats and businessmen ${ }^{38}$. The members of this milieu, steeped in the culture and refinement of the Greek 
world, strove to outdo each other in the opulence of the reception rooms of their houses. The abundance of imagery from the iconographic cycles of Dionysos and Aphrodite and the exotic or grotesque subjects in the statuary, furniture and vessels of the Mahdia shipwreck reveal that these works were destined for domestic leisure space.

If indeed the Getty herm, which is almost the twin of the Dionysiac herm from the shipwreck, signed by Boethos, is ancient, the Mahdia herm is then not unique ${ }^{39}$. Its shaft was formed employing the direct method, while the genitals and the arm bosses were modeled on wax sheets attached to the shaft. Use of the indirect method has been detected in the shaping of the head, where vent channels and lead segregation prove that the figure was cast upside down ${ }^{40}$. The technique of pounding patches of bronze in spots with casting flaws by applying an intermediate lead strip to the cavity was first noticed in the Mahdia herm ${ }^{41}$. The surprisingly similar composition of the alloys of both herms ${ }^{42}$ may offer another means for identifying workshops and putting together a chronology, as has been attempted in other cases. A data bank of alloys for replicas would prove to be very helpful.

The lessons learned from the study of the Mahdia finds is very instructive, when one turns to the Antikythera shipwreck (fig. 6), which is dated to the second quarter of the 1st century B.C. ${ }^{43}$ The goods transported by this vessel, albeit not yet recovered in their entirety, are more heterogeneous than those found in the Mahdia wreck ${ }^{44}$. We have original bronze statues such as those of the "Antikythera Youth" and the "Philosopher", along with fragmentary limbs from other statues and attributes, 5 classicizing bronze statuettes, 36 statues of Parian marble, both larger and smaller than life-size, depicting gods, heroes and mortals, 3 bronze couches, pots of copper, silver, lead and tin, gold jewelry, 20 glass vessels,

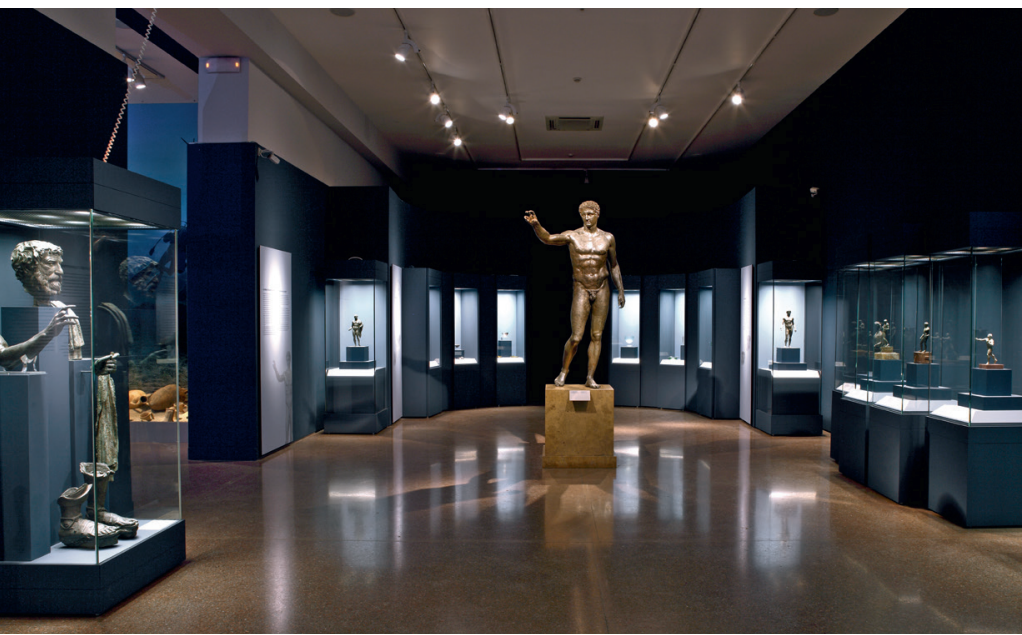

Fig. 6. The "Philosopher of Antikythera" and the "Antikythera Youth": a view of the Antikythera shipwreck's exhibition at the National Archaeological Museum, Athens. (C) Hellenic Ministry of Culture and Sports/Archaeological Receipts Fund/Eirene Miari.
29 amphorae from Rhodes, Kos and Ephesos, 47 lagynoi, fine red slipped tableware, 10 clay lamps, 36 cistophoric tetradrachms issued in Ephesos and Pergamon and 48 bronze coins, as well as the legendary Antikythera Mechanism itself. This collection, along with the fact that most of the statuary has been detached from where it originally stood and that the Mechanism is unique, suggests an act of pillage, rather than a commercial transaction, despite earlier suggestions that the presence of the marble statues would be consonant with mercantile activity (commission to a sculpture workshop or art dealer $)^{45}$. Furthermore, the different profile, in terms of artistic evolution of the Antikythera statuary, when compared with the Mahdia finds, should be emphasized. In the Mahdia finds, the language of sculpture is in conformity with the Late Hellenistic idiom, whereas in the case of the Antikythera wreck, the Late Hellenistic style accentuates Classical forms of expression ${ }^{46}$.

The marble statues from the Antikythera wreck are copies or variations of famous works of art from Classical antiquity, classicizing creations, works recalling productions of the Early and Middle Hellenistic periods, and originals of the Late Hellenistic period ${ }^{47}$. The high polish applied to the torso of the Antikythera young wrestler (inv. $n^{\circ} 2773$ ) is a typical feature from the Late Hellenistic period onwards ${ }^{48}$. The Antikythera Homeric heroes are novel creations of the 1st century B.C. ${ }^{49}$

The earliest of the bronze objects from the Antikythera shipwreck - the Youth (inv. $\mathrm{n}^{\circ} \mathrm{X} 13396$ ) - dates to the middle of the 4th century B.C. while the latest ones were created around 100 B.C. ${ }^{50}$ (fig. 10-11). To the cast bronze statue of the Philosopher (fig. 7) are assigned a head, hands and sandaled feet, and fragments of a himation. The statue is dated to ca. 230 B.C., or shortly after, and perhaps depicts the philosopher Bion the Borysthenite from Olbia ${ }^{51}$. The presence of fragments of arms from other similarly-sized bronze statues in gestures comparable to that of the Philosopher, and pieces of legs wearing identical leather sandals lead to the conclusion that they belonged to a group consisting of at least four honorary statues of philosophers, orators of state officials set in a public place (fig. 8-9) ${ }^{52}$. Variations are obvious in the rendering of the details, thanks to the freedom of the sculptor who enjoyed to make changes on the wax model. This technical procedure, necessary to differentiate the depicted personalities, cannot obscure the various contributions by the different artists involved. The thin walls of the Philosopher statue and of a hand from the same composition, which served to reduce weight and production costs, mark a technological advance and reveal the technique of a foundry with great confidence and skill ${ }^{53}$.

The five male statuettes between 24 and $50 \mathrm{~cm}$ in height from the Antikythera shipwreck show the use of separately cast limbs. They are assigned to the late 2 nd century B.C. ${ }^{54}$ Four of them had inlaid irises in the eyes, and nipples on the chest. If the male statuette, with a chlamys over the left torso and arm, which echoes Polykleitan contraposto renders Hermes (fig. 10, inv. $\mathrm{n}^{\circ} \mathrm{X} 13398$ ), then the predilection for 


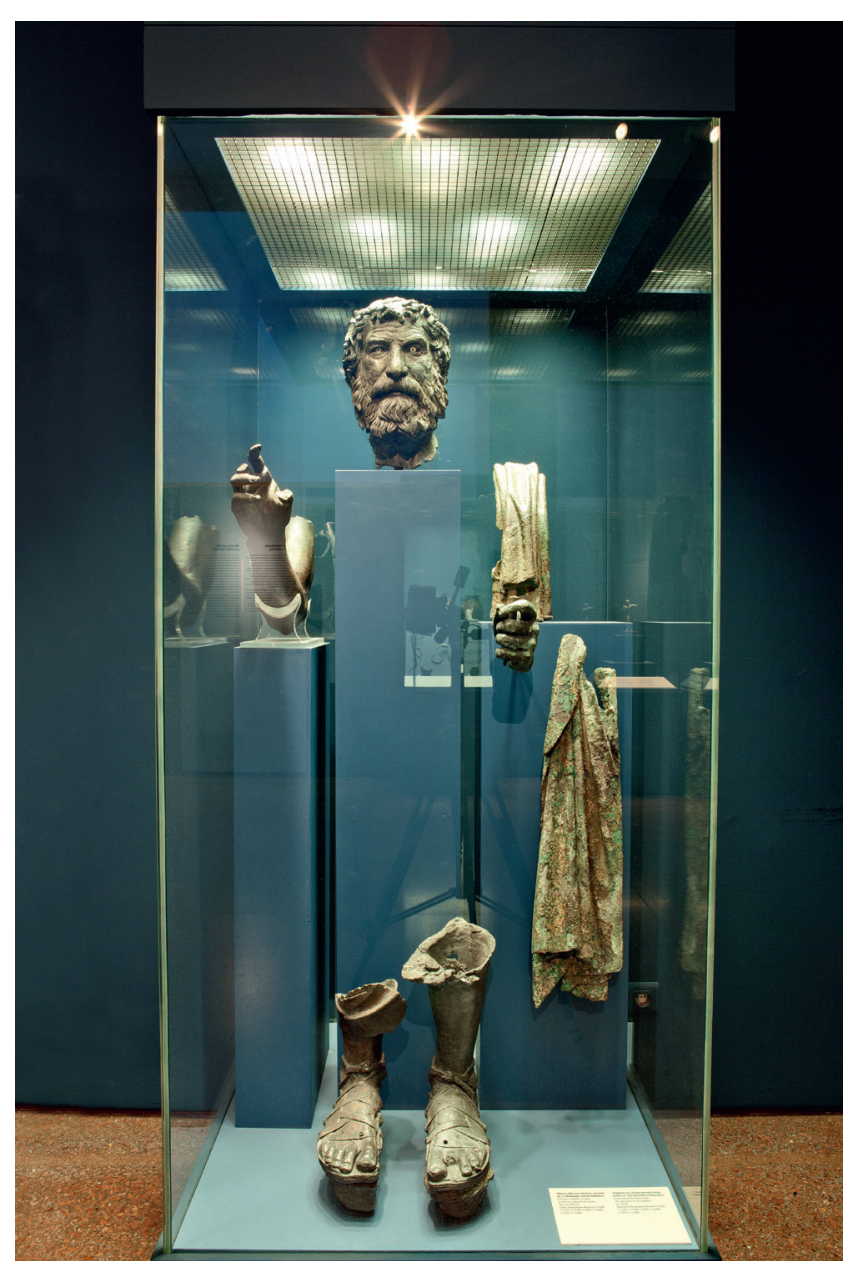

Fig. 7. Head, hands, sandaled feet and fragments of the himation of the bronze statue of a Philosopher, Antikythera shipwreck, Athens, National Archaeological Museum, inv. nos X 13400, X 15105, X 15108, X 15091, X 15090, X 18932, X 15088. @ Hellenic Ministry of Culture and Sports/Archaeological Receipts Fund/Eirene Miari.

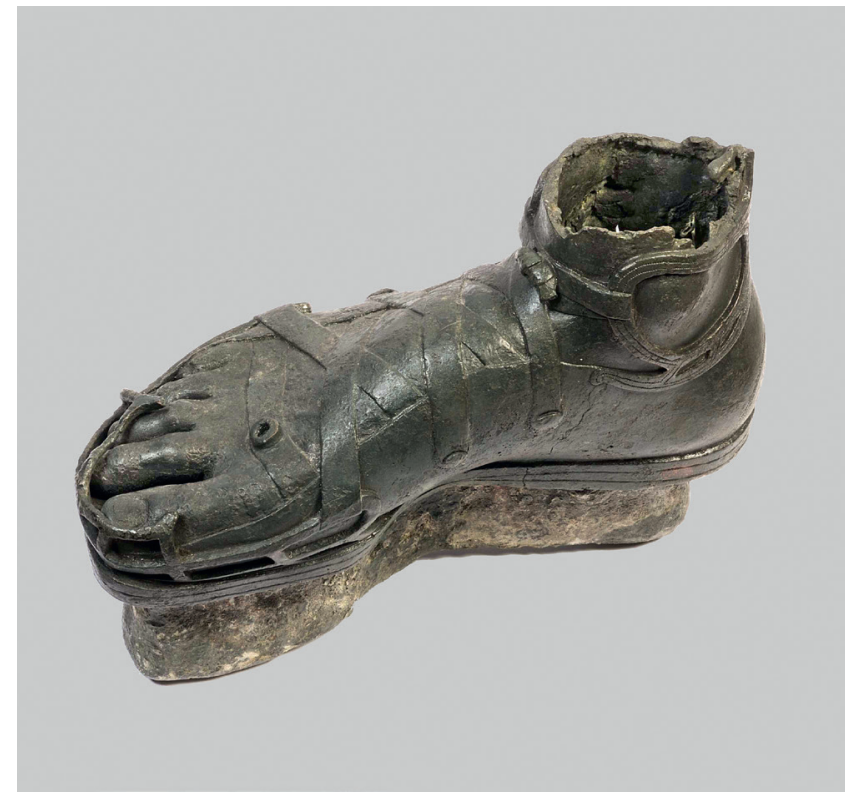

Fig. 8. Right sandaled foot of a bronze male statue, Antikythera shipwreck, Athens, National Archaeological Museum, inv. $\mathrm{n}^{\circ} \mathrm{X}$ 15092. ( ) Hellenic Ministry of Culture and Sports/Archaeological Receipts Fund/Kostas Xenikakis.

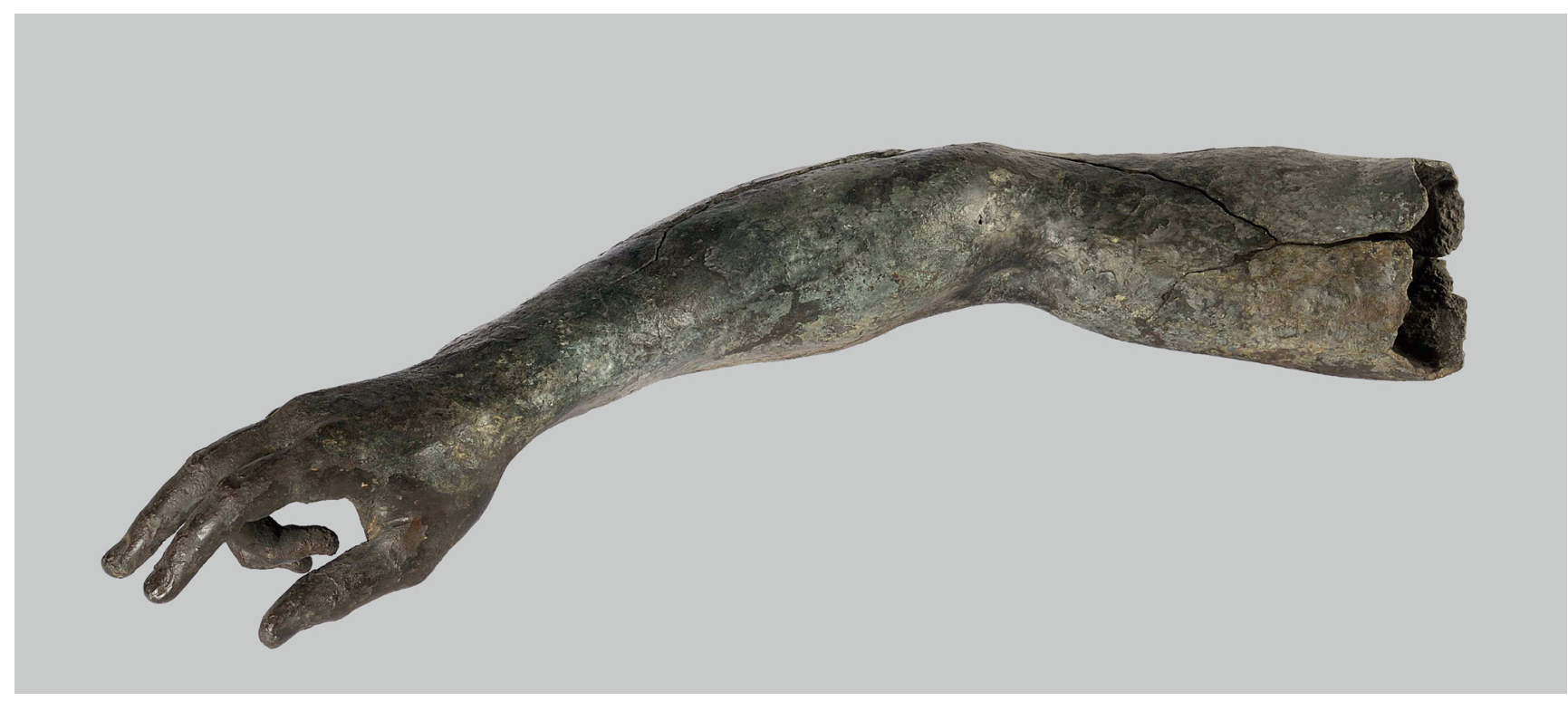

Fig. 9. Right arm of a bronze male statue, Antikythera shipwreck, Athens, National Archaeological Museum, inv. $\mathrm{n}^{\circ} \mathrm{X} 15107$. (c) Hellenic Ministry of Culture and Sports/Archaeological Receipts Fund/Kostas Xenikakis. 


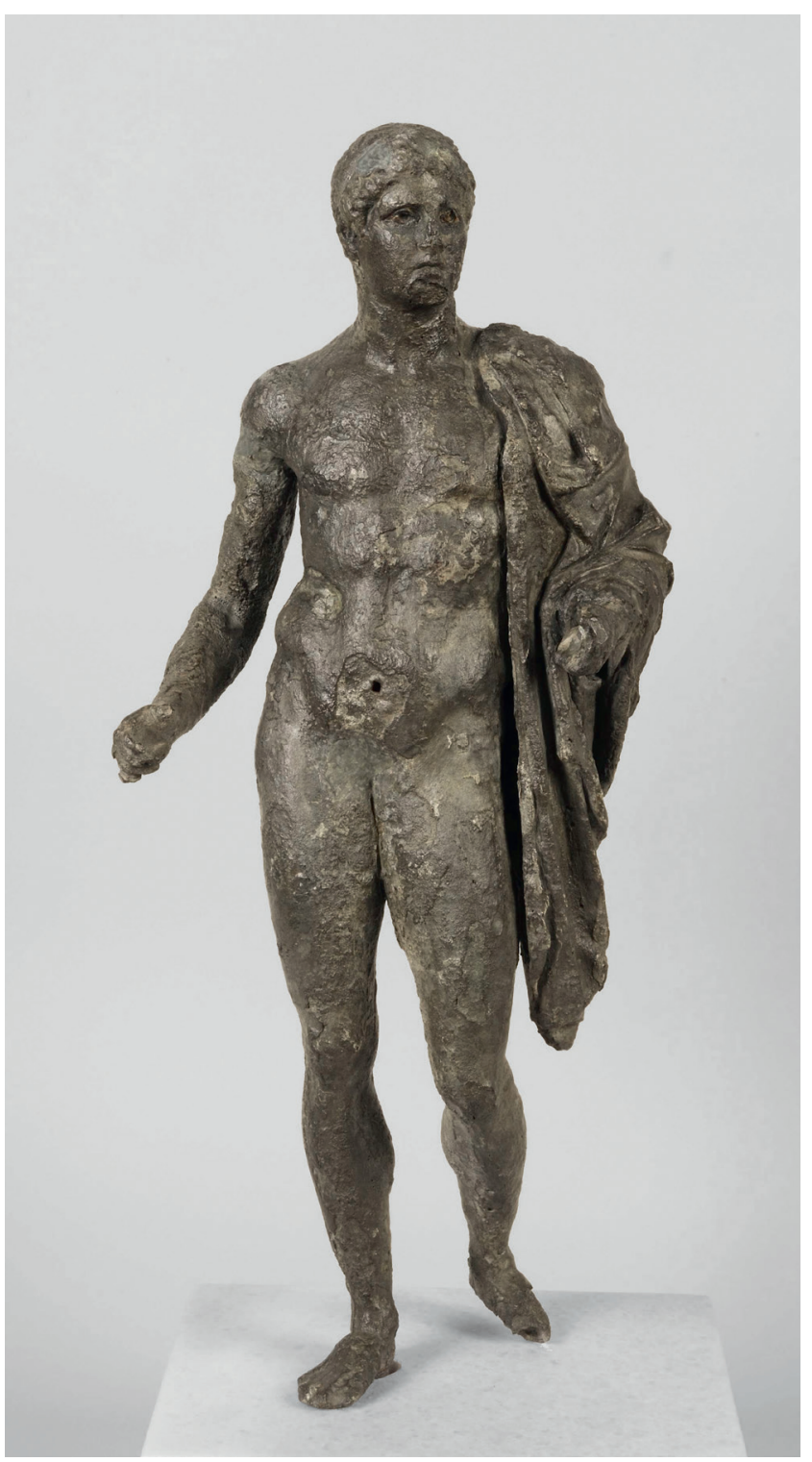

Fig. 10. Statuette of Hermes (?), Antikythera shipwreck, Athens, National Archaeological Museum, inv. $n^{\circ}$ X 13398. (C) Hellenic Ministry of Culture and Sports/Archaeological Receipts Fund/Kostas Xenikakis.

this specific divinity on behalf of the businessmen is apparent and understandable. Hermes (and herms), of course, was also dominant among the traditional household deities in the Hellenistic period ${ }^{55}$. It is noteworthy that the statuette of one of the youths (fig. 11, inv. $n^{\circ} \mathrm{X} 18957$ ) rotated on a cylindrical base. The key to wind up the mechanism, which was set in a hole of the base, transferred movement by means of a dowel to the rotation mechanism. This fact is revealing of a new approach to art, which, stripped of its religious and votive connotations, is now envisaged as merely an object of admiration ${ }^{56}$. Thus this collection of five youths, for the most part athletes, were highly desirable, as finds from excavated Roman villas show, not so much for the ideals they incorporated, but rather for their contribution to the growing luxury of their owners ${ }^{57}$.

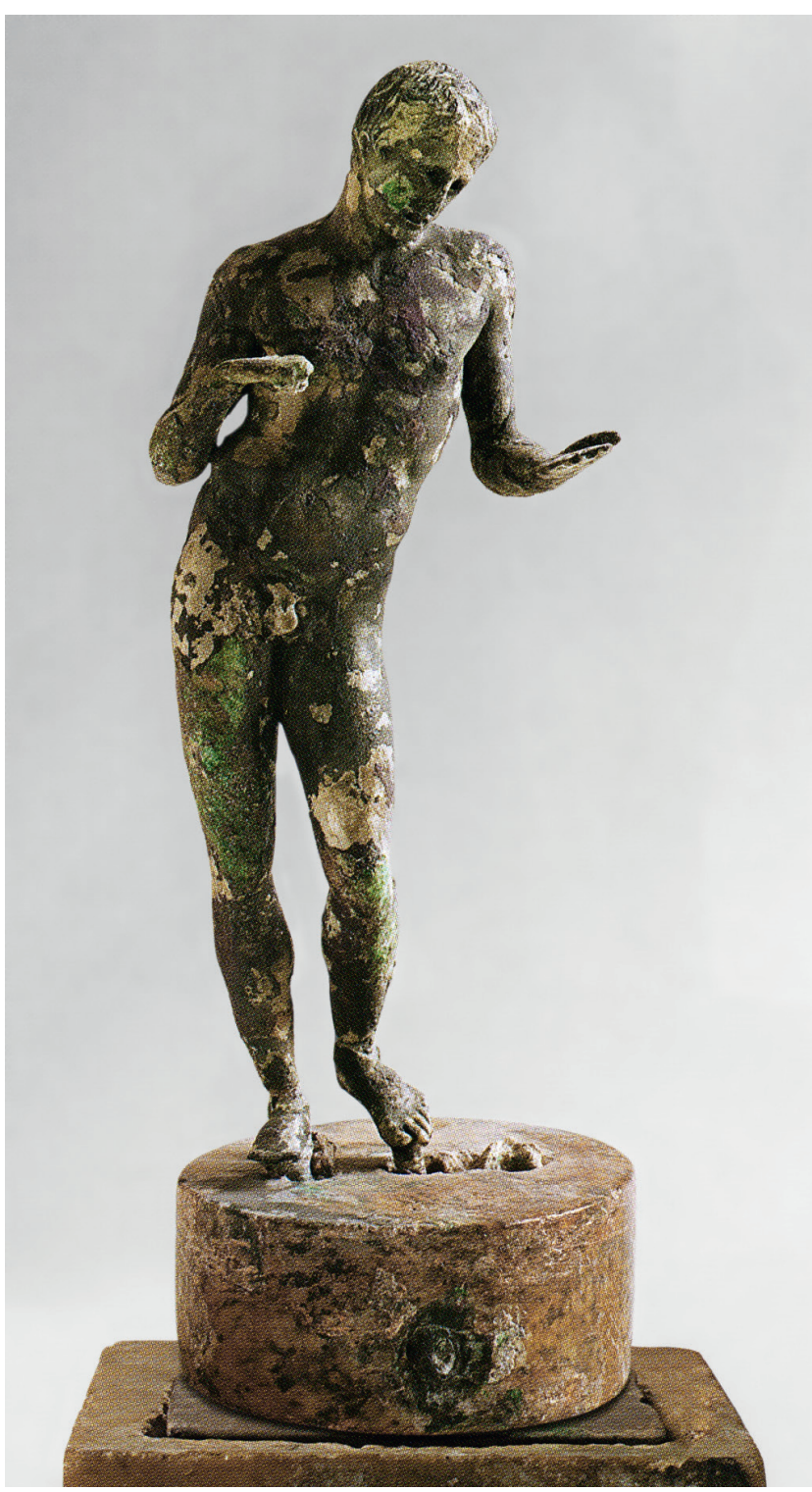

Fig. 11. Statuette of a youth, Antikythera shipwreck, Athens, National Archaeological Museum, inv. $n^{\circ}$ X 18957. () Hellenic Ministry of Culture and Sports/Archaeological Receipts Fund/Kostas Xenikakis.

The eight copies of the Apoxyomenos so far known confirm the love for athletes' statues and furnish ample and solid evidence for the practice of copying large scale statues, in both marble and basalt and in bronze. The Ephesos statue now in Vienna and the Athlete of Croatia are almost identical in their dimensions, posture and details ${ }^{58}$. The head at the Fort Worth Kimbell Art Museum displays close similarities to those of the two entirely restored statues. They are thought to derive from an original of around the middle of 4th century B.C. or a little earlier influenced by the post-Polykleitan school $^{59}$, although their hairstyle can be found in later periods.

The Apoxyomenos, now in Vienna, had been placed in the gymnasium of Ephesos at the end of the 1st or early 2nd century A.D. ${ }^{60}$ Like its counterpart from Croatia ${ }^{61}$, it is made of several parts and its lips and nipples are executed in copper 
sheet. This practice, attested as early as the 5th century B.C., flourishes until the Early Imperial period ${ }^{62}$. The head is attached to the neck in the same way in both the Croatian youth and the head at Fort Worth, in a fashion characteristic of the 1 st century B.C. and the Early Imperial period ${ }^{63}$. Both bronze statues of Apoxyomenos from Ephesos and Croatia have a close thickness of walls: 3-8 $\mathrm{mm}$ and 5-7 $\mathrm{mm}$, respectively. There is a small proportion of lead in the alloy of the Croatian bronze ${ }^{64}$. This fact, together with the careful corrections of casting defects, the accurate soldering of the hips, and the bronze plinth of the base may indicate a product of Greek technology, in the view of N. Cambi ${ }^{65}$. V. Saladino, on the other hand, suggested that the large patches of irregular shape with convex surfaces give an indication of the date, but he thinks that the composition of the alloy is not a secure dating clue ${ }^{66}$.

The Apoxyomenos of Croatia, a Hellenistic copy of the 2nd or 1st century B.C. ${ }^{67}$, was recovered from the sea off the island Lošinj. It was probably rejected in order to lighten and save the ship, which was sailing north to cities, such as Aquileia, Ravenna or Pula, or to a villa, such as that in the Verige Bay ${ }^{68}$. Only an arm of an anchor and amphora fragments were found in its vicinity. Uncertainties regarding its date might be clarified, at least at the lower limit, by a terminus ante quem that a shipwreck could furnish.
The merit of shipwreck contexts in offering information regarding the production date, and circulation of bronze statuary is not to be disregarded. As stressed above, various practices observed in the Late Hellenistic wrecks with art works may advance the discussion on replicas and their dating:

- Lack or scarcity of original large scale bronzes among the luxury goods is a fact.

- Replicas of large scale statues are made not only in stone but also in bronze.

- The small bronzes are serially produced by means of the indirect lost wax technique.

- Bronze bases could be used for both large and small scale statuary.

- Statuettes decorating utensils in new ways or provided with rotating mechanism are a novelty.

- Statues or busts of Athena and philosophers, sculpture inspired from the world of Dionysos and Aphrodite, as well as herms were coveted for libraries, gardens, reception rooms, and exercise areas, respectively.

- Techniques for casting, welding, soldering, repair of flaws, workmanship, and, eventually, alloys, are sometimes very indicative in this field of inquiry, if combined with other parameters.

Thus, the sunken cargoes of the 1st century B.C., in particular, are extremely enlightening, for they reflect more vividly the current trends in art creation and its trade.

\section{Notes}

1. For the relevant entries, see Parker,

1992, passim and Gelsdorf, 1994, p. 761-766.

2. Saladino, 1998, p. 4.

3. Hellenkemper Salies, 1994, p. 17-18.

4. Exp. Athènes, 2012.

5. Baudoin, Liou, Long, 1994.

6. Baudoin, Liou, Long, 1994, p. 105. p. 290.

7. Bouyia, 2012a, p. 38; Bouyia, 2012b,

8. Wünsche, 1979, p. 77-111; Gelsdorf, 1994 , p. $765, \mathrm{n}^{\circ} 41$; Touratsoglou, 2011, p. $370-372$.

9. Touratsoglou, 2011, p. 376, n. 14.

10. Koutsouflakis, 2007 , p. $42-56$.

11. Tchernia, 1969, p. 492; Parker, 1992 , p. $377 n^{\circ} 1012$; Valaison, 1970, p. 179-185.

12. Information provided by the Ephorate of Underwater Antiquities.

13. Baudoin, Liou, Long, 1994, p. 31.

14. Baudoin, Liou, Long, 1994, p. 105.

15. Vlachogianni, 2012b, p. 40-41.

16. Hellenkemper Salies, 1994, p. 24.

17. Höckmann, 1994, p. 473.

18. Linfert, 1994, p. 835, 843.

19. Bronze objects from the Mahdia

shipwreck are kept in the musée national du

Bardo, Tunis (Tunisia). Höckmann, 1994, p. $469-472$.

20. Höckmann, 1994, p. 473.

21. Höckmann, 1994, p. 475.

22. Pfisterer-Haas, 1994, p. 489-491.
23. Mattusch, 1994, p. 795-796.

24. Hiller, 1994, p. 515, 519; Mattusch,

1994 , p. 795.

25. Hiller, 1994, p. 525.

26. Hiller, 1994, p. 522.

27. Hiller, 1994, p. 527.

28. Böhm, 1994, p. 506-508.

29. Klages, 1994 , p. 532-533.

30. Hiller, 1994, p. 527; Bauchhenß-

Thüriedl, 1994, p. 542.

31. Klages, 1994, p. 537; Naumann-

Steckner, with T. Raeder and F. Willer, 1994 , p. 631. 546 .

32. Bauchhenß-Thüriedl, 1994, p. 542,

33. Barr-Sharrar, 1994a, p. 559-572.

34. Faust, 1994, p. 573-606. For fulcra

with a protome of Artemis in the medallion, see Fuchs, 1963, p. 33 n $^{\circ} 40$; for those decorated with themes from the Aphrodite

cycle, see Lilibaki-Akamati, 1979, p. 142.

35. Baratte, 1994, p. 607-628.

36. Barr-Sharrar, 1994b, p. 639-655.

37. Barr-Sharrar, 1994 c, p. 657-661.

38. Mattusch, 1994, p. 798

39. Mattusch, 1994, p. 796-797; and in this volume.

40. Willer, 1994, p. 959-963, 965 fig. 10

and colored table 33 .

41. Willer, 1994, p. 968

42. Mattusch, 1994, p. 796.

43. Exp. Athènes, 2012

44. Bouyia, 2012c, p. 29-31.
45. Vlachogianni, 2012a, p. 70. 46. Hellenkemper Salies, 1994, p. 19; Himmelmann, 1994, p. 851-855.

47. Marble statues from the Antikythera shipwreck are kept in the National Archaeological Museum, Athens.

Vlachogianni, 2012a, p. 72.

48. Vlachogianni, 2012b, p. 43

49. Vlachogianni, 2012a, p. 68-70.

50. Bronze objects from the

Antikythera shipwreck are kept in the

National Archaeological Museum, Athens. Bouyia, 2012d, p. 48

51. Vlachogianni, 2012a, p. 82-86, no 24 (inv. $\mathrm{n}^{\text {os }}$ X 13400, X 15105, X 15108, X 15091, X 15090, X 18932, X 15088). 52. Vlachogianni, 2012a, p. 62-63,

$86-88, n^{\text {os }} 25-29$, p. $90-91, n^{\text {os }} 31-33$

53. Mattusch, 1996, p. 94, 169.

54. Vlachogianni, 2012a, p. 93-97,

$\mathrm{n}^{\text {os }} 38-42$ (inv. $\mathrm{n}^{\text {os }} \mathrm{X} 13397, \mathrm{X} 13398$,

X 13399, X 18957, X 18958).

55. Sharpe, 2006, p. 68.

56. Sharpe, 2006, p. 72.

57. Sharpe, 2006, p. 176.

58. Cambi, 2006, p. 24.

59. Michellucci, 2006, p. 19; Cambi

2006, p. 26-27; Saladino 2006, p. 40-41.

60. Vienna, Kunsthistorisches

Museum/Ephesos Museum, inv. n VI 3168.

Saladino, 2006, p. 35; Plattner, in this volume. 61. The Apoxyomen Museum, Mali

Lošinj, Croatia. Saladino, 2006, p. 43. 
62. Saladino, 2006, p. 47.

63. Saladino, 2006, p. 46-47.

64. Saladino, 2006, p. 42.

65. Cambi, 2006, p. 28.

66. Saladino, 2006, p. 46-47.

67. Cambi, 2006, p. 29.

68. Karniš et al., 2006, p. 74.

\section{Bibliography}

Baratte F., 1994, "Les candélabres », dans Exp. Bonn, p. 607-628.

Barr-Sharrar B., 1994a, "The bronze appliques”, dans Exp. Bonn, p. 559-572.

Barr-Sharrar B., 1994b, "The bronze lamps", dans Exp. Bonn, p. 639-655.

Barr-Sharrar B., 1994c, "Rolling brazier", dans Exp. Bonn, p. 657-661.

Bauchhenß-Thüriedl C., 1994, "Zwei Schauspieler Statuetten”, dans Exp. Bonn, p. 539-549.

Baudoin C., Liou B., Long L., 1994, « Une cargaison de bronzes hellénistiques. L'épave Fourmigue C à Golfe-Juan ", Paris, Archaeonautica, 12.

Böhm S., 1994, "Zwei Erotenstatuetten", dans Exp. Bonn, p. 505-514.

Bouyia P., 2012a, "The ship", dans Exp. Athènes, p. 36-39.

Bouyia P., 2012b, "Maritime commerce and luxury in the age of Cicero", dans Exp. Athènes, p. 287-292.

Bouyia P., 2012c, 2012, "The Antikythera shipwreck", dans Antikythera, Technology, Athens, p. 29-31.

Bouyia P., 2012d, "Bronze working", dans Antikythera, Technology, Athens, p. 48-55.

Cambi N., 2006, "The athlete cleaning a strigil”, dans Michellucci (dir.), p. 21-33.

Christopoulou A., Gadolou A. et Bouyia P. (dir.), 2012, "The Antikythera shipwreck. The technology of the ship, the cargo, the Mechanism", Antikythera, Technology, Athens.

Exp. Athènes, 2012 : The Antikythera shipwreck: the ship, the treasures, the mechanism [Athens, National Archaeological Museum, April 2012April 2013], Kaltsas N., Vlachogianni E., Bouyia P. (dir.)], Athens.
Exp. Bonn, 1994 : Das Wrack. Der antike Schiffsfund von Mahdia [Rheinisches Landesmuseum Bonn, 8. September 1994-29. Januar 1995], Hellenkemper Salies G., von Prittwitz und Gaffron H.-H., Bauchhenß G. (dir.)], (Kataloge des Rheinischen Landesmuseum Bonn, 1), Köln.

Faust S., 1994, "Die Klinen”, dans Exp. Bonn, p. 573-606.

Fuchs W., 1963, Das Schiffund von Mahdia, Tübingen.

Gelsdorf F., 1994, "Antike Wrackfunde mit Kunsttransporten im Mittelmeer", dans Exp. Bonn, p. 759-766.

Hellenkemper Salies G., 1994, "Der antike Schiffsfund von Mahdia. Entdeckung und Forschung", dans Exp. Bonn, p. 5-29.

Hiller H., 1994, "Zwei bronzene Figurenlampen", dans Exp. Bonn, p. 515-530.

Himmelmann N., 1994, "Mahdia und Antikythera”, dans Exp. Bonn, p. 849855.

Höckmann U., 1994, "Die Hermesstatuette”, dans Exp. Bonn, p. 469-481.

Karniš I. et al., 2006, "Story of a recovery", dans Michellucci M. (dir.), Apoxyomenos. The athlete of Croatia, Florence, p. 65-107.

Klages C., 1994, "Die Satyrstatuetten”, dans Exp. Bonn, p. 531-538.

Lilimbaki-Akamati M., 1979, « Xá $\lambda_{\kappa} \iota v o$

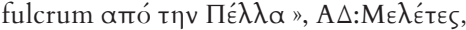
p. $138-149$

Koutsouflakis G., 2007, "Xá $\lambda$ kıvos kopнós

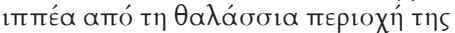
Ka $\lambda u ́$ uvou ", Evá $\lambda_{1} \alpha$ 10, p. 42-56.

Linfert A., 1994, "Boethoi”, dans Exp. Bonn, p. 831-847.

Mattusch C. C., 1994, "The production of bronze statuary in the Greek world", dans Exp. Bonn, p. 789-800.

Mattusch C. C., 1996, The Fire of Hephaistos: Large Classical Bronzes from North American Collections, published in conjunction with the exhibition organized by the Harvard University Art Museums [Cambridge MA, Arthur M Sackler Museum, Harvard University Museums of Art, 20 April-11 August 1996; Toledo, the Toledo Museum of Art, 13
October 1996- 5 January 1997; Tampa, the Tampa Museum of Art, 2 February-13 April 1997], Cambridge MA.

Michellucci M. (dir.), 2006, Apoxyomenos. The athlete of Croatia, Florence.

Naumann-Steckner F., en collaboration avec Raeder T. et Willer F., 1994, "Ein Kandelaber mit Akanthusranken?”, dans Exp. Bonn, p. 629-638.

Parker A., 1992, Ancient Shipwrecks of the Mediterranean and the Roman provinces, Oxford $(B A R, 580)$.

Pfisterer-Haas S., 1994, "Die bronzenen Zwergtänzer”, dans Exp. Bonn, p. 483504

Saladino V., 1998, "Artisti greci e commitenti romani”, dans S. Settis (dir.), I Greci. Storia, Cultura, Arte, Società, 2. Una storia greca, III. Trasformazioni (IV secolo a.C. II secolo d.C.), Torino, p. 1-35.

Saladino V., 2006, "The athlete with a strigil", dans Michellucci (dir.), p. 35-51.

Sharpe H. F., 2006, From hieron and oikos: The religious and secular use of Hellenistic and Greek Imperial bronze stautuettes, Diss. Indiana University.

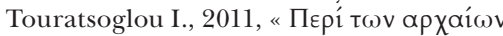

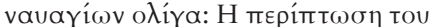
Aртєцıбíou ", dans A. Delivorrias, G. Despinis, A. Zarkadas (dir.), EПAINO $\Sigma$ Luigi Beschi, Athens $=($ Mouseio Benaki: 7th Supplement), p. 369-380.

Tchernia M. A., 1969, « Direction des recherches archéologiques sousmarines ", Gallia 27:2, p. 465-499.

Valaison F. et M.-C., 1970, "Statuette de bronze découverte au large des SaintesMaries-de-la Mer », Revue archéologique de Narbonnaise 3, p. 179-185.

Vlachogianni E., 2012a, "Sculpture", dans Exp. Athènes, p. 62-79.

Vlachogianni E., 2012b, "Sculpture", Antikythera, Technology, p. 40-45.

Willer F., 1994, "Zur Herstellungstechnik der Herme”, dans Exp. Bonn, p. 959970 .

Wünsche R., 1979, "Der Gott aus dem Meer", JdI 94, p. 77-111. 